\author{
Коробка Лариса Миколаївна \\ кандидат психологічних наук, старший науковий співробітник, \\ завідувач лабораторії психології мас та спільнот, \\ Інститут соціальної та політичної психології НАПН України, \\ м. Київ, Україна \\ ORCID ID 0000-0001-9306-0624 \\ larisakorobka@gmail.com
}

\title{
ПСИХОЛОГІЧНІ ЗАСОБИ ПІДВИЩЕННЯ АДАПТИВНОСТІ СПІЛЬНОТИ ДО НАСЛІДКІВ ВОСННОГО КОНФЛІКТУ
}

\begin{abstract}
За результатами узагальнення і систематизації даних теоретичного та емпіричного вивчення проблеми психологічних стратегій адаптації спільноти до умов і наслідків воєнного конфлікту в процесі зміцнення громадського здоров'я представлено організацію дослідження з метою вироблення й апробації психологічних засобів підвищення адаптивності спільноти. Обгрунтовано теоретичні засади вироблення психологічних засобів та необхідність їх застосування для підвищення адаптивності спільноти до наслідків воєнного конфлікту та зміцнення як індивідуального, так і громадського здоров'я. Запропоновано соціально-психологічну модель зміцнення громадського здоров'я як умови адаптації спільноти до кризових умов життя, у якій зроблено акценти: на сприянні комунікації, спрямованій на поліпшення поінформованості з питань здоров'я, підвищення відповідальності в ставленні до нього та набуття компетентності щодо його збереження; на посиленні відчуття зв'язності та підвищенні психологічної пружності як здатності жити повноцінним і продуктивним життям попри різні обмеження, зберігати і підвищувати рівень благополуччя; на посиленні здатності використовувати стресову ситуацію як можливість для подальшого розвитку, тобто на посттравматичному зростанні; на посиленні рефлексивних процесів та активізації індивідуальних і колективних ресурсів для подолання наслідків воєнного конфлікту. Розкрито зміст розробленої програми соціально-психологічної роботи, спрямованої на підвищення рівня когнітивної, емоційної та поведінкової компетентності громади, зокрема представників педагогічної спільноти, 3 метою активізації ресурсів підвищення адаптивності та зміцнення здоров'я як умови адаптації до складних життєвих ситуацій. Здійснено аналіз отриманих результатів апробації психологічних засобів, які засвідчили можливість і перспективність запобігання негативним наслідкам воєнного конфлікту через посилення відчуття зв'язності як здатності контролювати здоров'я та добробут; самоефективності як основи людської суб'єктності; індивідуальної і колективної рефлексивності щодо важливості та можливості активізації індивідуальних і колективних зусиль, спрямованих на підвищення адаптивності та подолання негативних соціально-психологічних наслідків воєнного конфлікту.
\end{abstract}

Ключові слова: адаптація; стратегії адаптації; спільнота; психологічні засоби; підвищення адаптивності; наслідки воєнного конфлікту; зміцнення громадського здоров’я.

\section{PSYCHOLOGICAL MEANS FOR IMPROVING THE COMMUNITY'S ADAPTABILITY TO THE CONSEQUENCES OF THE ARMED CONFLICT}

\section{Larysa M. Korobka}

$\mathrm{Ph}$. D. in Psychology, Senior Researcher,

Head of the Laboratory of Psychology of Masses and Communities

Institute for Social and Political Psychology,

National Academy of Educational Sciences of Ukraine

Kyiv, Ukraine

ORCID ID 0000-0001-9306-0624

larisakorobka@gmail.com

Abstract. According to the generalized and systematized results of a theoretical and empirical study of the psychological strategies of community adaptation in the process of public health's strengthening, it is presented the organization of a study on the development and testing the psychological tools for increasing the community's adaptability to the conditions and consequences of armed conflict. The theoretical foundations of the development of psychological means of adaptation are grounded, as well as the necessity of their application in order to increase the community's adaptability to the consequences of armed conflict, to strengthen both 
individual and public health. The socio-psychological model for strengthening the public health (as a condition of community's adaptation to crisis conditions of life) is presented. The model focuses on: the promotion of communication aimed to improve health awareness, to increase health responsibility, and to gain competence in health preservation; the enhancement of the sense of coherence and the promotion of psychological resilience (as an ability to live a full and productive life despite different constraints); the increasing of the ability to use a stressful situation as an opportunity for further development (post-traumatic growth); the strengthening of reflexive processes and increasing the readiness for change; the activation of individual and collective resources to cope the outcomes of an armed conflict. It is disclosed the content of the elaborated program of sociopsychological work aimed to raise the level of cognitive, emotional and behavioral competence (in particular among the representatives of the pedagogical community), aiming to activate the adaptability resources and health promotion as a form of adaptation to difficult life conditions. It is analyzed the approbation of psychological means, which showed the possibility and the prospectivity of negative consequences' preventing in an armed conflict by improving the sense of connectivity (as an ability to control health and well-being); the self-efficacy (as the basis of human subjectivity); the individual and collective reflexivity about the importance and opportunities for intensifying of individual and collective efforts to improve adaptability and to overcome the negative socio-psychological consequences of armed conflict.

Key words: adaptation; adaptation strategies; community; psychological means; adaptability improving; consequences of an armed conflict; public health' strengthening.

Постановка проблеми. Дослідження адаптаційних процесів спільноти в умовах воєнного конфлікту зосереджено не лише на складностях їхнього перебігу в умовах війни, а й на пошуку успішних психологічних стратегій пристосування та вироблення соціально-психологічних засобів подолання негативних наслідків цих подій у різних сферах життєдіяльності, що й стало завданням дослідної роботи лабораторії психології мас та спільнот за темою "Психологічні стратегії адаптації спільноти до умов і наслідків воєнного конфлікту”. Вироблення та застосування таких засобів сприятиме запобіганню негативним соціально-психологічним наслідкам воєнного конфлікту та їх подоланню на двох рівнях (спільноти як структурної одиниці суспільства і життєдіяльності особи в значущому для неї середовищі); корекції поведінки представників різних спільнот в умовах соціальних викликів, усвідомленню можливостей активізації колективних зусиль 3 підвищення адаптивності спільноти до наслідків воєнного конфлікту.

Отже, проблема адаптації спільноти до наслідків воєнного конфлікту зумовлює потребу пошуку ефективних соціально-психологічних засобів підвищення адаптивності представників спільноти, вироблення проактивно-трансформаційних психологічних стратегій адаптації до умов $\mathrm{i}$ наслідків воєнного конфлікту як найбільш ефективного варіанта індивідуальної і колективної зараджувальної поведінки в різних сферах життєдіяльності, активізації індивідуальних і колективних ресурсів зміцнення громадського здоров’я та подолання згаданих негативних наслідків.

Аналіз останніх досліджень і публікацій, виокремлення нерозв'язаних частин загальної проблеми. Дослідження психологічних стратегій адаптації спільноти до умов і наслідків воєнного конфлікту в процесі зміцнення громадського здоров'я (Коробка, 2018) показало необхідність проведення соціально-психологічної роботи, спрямованої на усвідомлення та активізацію ресурсів підвищення адаптивності та вироблення ефективних стратегій адаптації, посилення відповідальності в ставленні до здоров'я, а також відновлення і підвищення благополуччя як базової ознаки індивідуального та громадського здоров'я.

В основу вироблення психологічних засобів підвищення адаптивності спільноти до умов $\mathrm{i}$ наслідків воєнного конфлікту та зміцнення громадського здоров'я покладено:

- салютогенну концепцію (A. Antonovsky) та ïï основне поняття - відчуття зв'язності “sense of coherence" як стрижневий елемент стану здоров'я i визначальний чинник для досягнення та підтримання громадського здоров'я в сукупності трьох його складників: зрозумілість (comprehensibility) - переконаність у тому, що світ $є$ зрозумілий, багатозначний, послідовний; керованість (manageability) - переконаність у власній здатності зараджувати собі, покладаючись на власні ресурси або сторонню допомогу; сенсовність, (meaningfulness) - переконаність у тому, що життя має сенс, а його вимоги достойні того, щоб відповідати їм (Antonovsky, 1984; 1996);

- підхід “resilience” як відновлення і підвищення благополуччя та визнання активної ролі людей у створенні здоров’я, як динамічний процес, у якому позитивна адаптація відбувається в умовах негараздів; як збереження стану благополуччя, незважаючи на негаразди (Bonanno, 2004) та здатності до відновлювальних зусиль як окремої людини, сім'ї, так і громади, спільноти (Norris, Stevens, \& Pfefferbaum, 2008). 
- положення про адаптацію в складних життєвих ситуаціях як процес посттравматичного зростання ("post-traumatic growth”), який постає як результат оволодіння цією реальністю, що супроводжується позитивними змінами на рівні особистості, групи, соціуму (Климчук, 2016; Joseph, \& Linley, 2006, Tedeschi, \& Calhoun, 2004);

- положення соціально-когнітивної теорії самоефективності А. Бандури, згідно 3 якою утвердження самоефективності (Self-efficacy) є основою людської суб'єктності і являє собою переконаність особи в здатності керувати подіями, які впливають на ії життя, віру в себе та власну компетентність в різних сферах соціального життя (Бандура, 2000), зокрема й у сфері збереження здоров'я;

- положення про роль громади, спільноти у вирішенні проблем, пов'язаних із підтриманням та збереженням здоров'я населення, їхню спроможність до цілеспрямованої діяльності в цій сфері та колективної рефлексії (Кривоконь, 2015; Найдьонова, 2015; Журавлев, \& Нестик, 2012).

Мета статті - представити соціально-психологічні засоби підвищення адаптивності спільноти до наслідків воєнного конфлікту, розроблені на основі моделі зміцнення громадського здоров'я, та результати їх апробації.

Виклад основного матеріалу дослідження. Теоретичний та емпіричний аналіз проблеми дав підстави для побудови соціально-психологічної моделі зміцнення громадського здоров'я як умови адаптації спільноти до кризових умов життя. У запропонованій моделі акценти зроблено на таких аспектах:

- сприяння тій чи іншій формі комунікації, спрямованій на поліпшення поінформованості 3 питань здоров'я та набуття компетентності щодо його збереження. Компетентність щодо питань здоров'я передбачає пізнавальні й соціальні уміння та навички досягнення благополуччя, визначальну мотивацію і здатність людей отримувати доступ до інформації, розуміти й використовувати їі так, щоб це сприяло зміцненню та підтримці здоров'я - як індивідуального, так і громадського;

- посилення відчуття зв'язності (sense of coherence), що сприятиме переходу від “орієнтації фактору ризику”, коли люди мають проблеми, до “салютогенної оріснтаціі”, коли вони сприймають потенціал та розвивають здатність контролювати власне здоров'я та добробут. У цьому контексті перш за все постає питання не про те, що є факторами ризику для захворювання, і як їм запобігти, а про те, що породжує здоров'я, які є засоби для зміцнення здоров'я, підвищення благополуччя і як їх можна використати. Це салютогенне питання зосереджує увагу на важливості пошуку ресурсів для створення здоров'я в контексті стресових ситуацій та кризових подій не лише на індивідуальному, а й на груповому та соціальному рівнях;

- сприяння психологічній стійкості, пружності (resilience) як здатності жити повноцінним і продуктивним життям попри різні обмеження та зберігати й підвищувати рівень свого благополуччя;

- посилення здатності використовувати стресову ситуацію як можливість для подальшого розвитку та досягнення більш високого рівня функціонування, тобто посттравматичне зростання (posttraumatic growth);

- активізація індивідуальних і колективних зусиль на подолання відстороненості в питаннях здоров’я та зростання відповідальності в ставленні до нього;

- підвищення індивідуальної і колективної самоефективності (Self-efficacy) як чинника зміцнення здоров'я;

- посилення рефлексивних процесів та зростання готовності до змін.

3 опорою на цю модель (з метою визначення та апробації засобів подолання наслідків воєнного конфлікту) було розроблено програму соціально-психологічної роботи, спрямованої на підвищення рівня когнітивної, емоційної та поведінкової компетентності представників педагогічної спільноти для активізації та розширення ресурсів підвищення адаптивності й зміцнення здоров'я як умови адаптації до складних життєвих ситуацій. Програма такої роботи складалася з трьох блоків: інформаційного (лекції-бесіди, інформаційно-діагностичні заняття), корекційно-розвивального (заняття з елементами соціально-психологічного тренінгу) та аналітичного.

Щоб вирішити завдання інформаційного блоку, з ініціативи автора було розроблено навчальну програму “Соціально-психологічні проблеми адаптації спільноти до кризових умов” для системи післядипломної педагогічної освіти. Її спрямовано на підвищення компетентності педагогічних працівників щодо соціально-психологічних проблем адаптації різних спільнот до кризових умов, активізацію зусиль педагогічної спільноти на підвищення адаптивності громадян до наслідків воєнного конфлікту та зміцнення здоров'я як умови адаптації до складних життєвих ситуацій. 
Програму курсу було впроваджено автором у навчальний процес Сумського обласного інституту післядипломної педагогічної освіти у 2017-2018н. p.

Метою реалізації навчальної програми було досягнення більш глибокого розуміння слухачами системи післядипломної педагогічної освіти соціально-психологічних проблем адаптації спільноти до кризових умов, підвищення компетентності щодо надання соціально-психологічної підтримки різним категоріям населення в процесі їхньої адаптації до кризових умов, зокрема до умов і наслідків воєнного конфлікту.

Матеріали навчальної програми розроблено з урахуванням сучасних теоретичних напрацювань 3 проблеми адаптації в психологічній науці та практики надання соціально-психологічної підтримки різним групам населення, що переживають наслідки травматичних подій. Особливу увагу приділено проблемі складнощів соціально-психологічної адаптації представників різних спільнот до умов і наслідків воєнного конфлікту; сутності позитивної адаптації спільноти до кризових умов як процесу посттравматичного зростання та його ролі в подоланні наслідків кризових і травматичних подій; формам і методам психолого-педагогічної підтримки різних категорій населення в процесі їхньої адаптації до кризових умов, якими мають оволодіти вчителі, психологи та соціальні педагоги закладів освіти.

Програму підготовлену з урахуванням отриманих під час виконання НДР “Психологічні стратегії адаптації спільноти до умов і наслідків воєнного конфлікту” результатів, що дає підстави говорити про наявність досить потужного адаптаційного ресурсу, який забезпечує успішність адаптації педагогічної спільноти. Програма містить необхідну суму знань, умінь і навичок, що допомагають поглибити розуміння педагогічними працівниками соціально-психологічних проблем адаптації спільноти до кризових умов; усвідомити роль педагогічної спільноти в розв'язанні цих проблем та ії спроможність до цілеспрямованої діяльності, консолідації зусиль, зокрема в напрямку підвищення адаптивності до суспільних змін, спричинених воєнним конфліктом, не лише своєї спільноти, а й інших груп населення.

Корекційно-розвивальний блок представлений заняттями 3 елементами соціальнопсихологічного тренінгу, спрямованими на:

- аналіз та усвідомлення впливу наслідків воєнного конфлікту як на особисте життя кожного 3 учасників, так і на життєдіяльність педагогічної спільноти та різних груп населення;

- усвідомлення наявних психологічних стратегій адаптації до таких наслідків та можливості їх оптимізації, що відбувається за рахунок сприяння усвідомленню ефективності/неефективності наявних стратегій та засвоєнню нових стратегій;

- активізацію рефлексивних умінь бачити ситуацію з різних сторін та в більш широкому соціальному контексті завдяки аналізу та інтерпретації соціальної ситуації;

- активізацію самопізнання щодо своїх емоційних станів, переживань, поведінки в складних життєвих ситуаціях, уявлень про себе та свої можливості;

- підвищення самоефективності та відчуття зв'язності (когерентності);

- посилення відповідальності в ставленні до здоров'я та підвищення психологічної пружності як здатності сприяти підвищенню благополуччя і на індивідуальному, і на колективному рівні;

- активізацію адаптаційного потенціалу, індивідуальних і колективних ресурсів у зміцненні здоров’я як умови адаптації до кризових умов;

- посилення індивідуальної та колективної рефлексивності щодо важливості й можливості активізації і нарощування адаптаційних ресурсів педагогічної спільноти.

У корекційно-розвивальній роботі брали участь дорослі особи віком від 29 до 52 років - три групи педагогів та практичних психологів закладів освіти, що проходили підвищення кваліфікації в Сумському обласному інституті післядипломної педагогічної освіти. Загальна кількість випробуваних, результати яких було враховано в аналізі ефективності корекційно-розвивального впливу, становила 35 осіб.

Результати впровадження програми сочіально-психологічної роботи було проаналізовано за об'єктивним (кількісні зміни показників) і суб'єктивно-оцінним (оцінка інформативної насиченості програми, іiї ефективності та можливості застосування набутих навичок і вмінь) критеріями, що становило зміст аналітичного блоку.

На початку і по завершенні такої роботи було проведено діагностику показників відчуття зв'язності як одного з провідних елементів стану здоров'я та його зміцнення; самоефективності як одного 3 предикторів поведінки, що сприяє зміцненню здоров'я; рівня вираженості і спрямованості 
рефлексії в процесі адаптації, подолання наслідків воєнного конфлікту та зміцнення громадського здоров'я. Аналіз результатів здійснено за допомогою статистичного пакету SPSS, використано непараметричний критерій Вілкоксона для зв'язаних вибірок щодо встановлення статистичної значущості відмінностей.

У корекційно-розвивальній роботі значна увага приділялася підвищенню рефлексивності педагогічної спільноти. Слід зазначити, що спільнота як велика соціальна група, члени якої безпосередньо можуть не взаємодіяти між собою, не позбавлена рефлексивності. Рефлективність спільноти, або колективна рефлективність, забезпечується не лише груповою взаємодією, а й індивідуальною рефлексією, спрямованою на колективне минуле, сьогодення і майбутнє. Отже, колективна рефлективність може накопичуватися в міжособовому спілкуванні, у спілкуванні між деякими представниками спільноти в межах невеликих груп, що об'єднують їі представників. Рефлективність у процесі міжособової взаємодії, як наголошують А. Журавльов і Т. Нестік, не втрачає свого колективного характеру, адже актуалізує групову ідентичність. Натомість межа, що розділяє індивідуальний і груповий рівень рефлексії, усе ще залишається спірною (Журавлев, \& Нестик, 2012). Дослідники зауважують, що змістом групової саморефлексії можуть бути цілі та сенс існування групи, реальні форми спільної життєдіяльності, потенційні можливості та ресурси спільноти, а також усе те, що було згаяне чи помилково реалізоване нею (Журавлев, 2009).

Процеси колективної рефлексії, осмислення, як правило, запускаються кризовими подіями, що й спонукало нас у контексті проблеми адаптації спільноти до наслідків воєнного конфлікту до активізації цих процесів у корекційно-розвивальній роботі з представниками педагогічної спільноти, зокрема зробивши акцент на змісті групової рефлексії щодо потенційних можливостей нарощування адаптаційних ресурсів спільноти, активізації колективних зусиль з подолання наслідків воєнного конфлікту та зміцнення громадського здоров'я.

Як зазначають дослідники, колективна рефлективність виконує такі соціально-психологічні функції, як адаптація групи до змін, підготовка до різних форм активності, формування уявлень про інші групи, про своє місце в системі соціальних відносин, підтримання позитивної групової ідентичності, а також формування колективної пам'яті та бачення майбутнього (Журавлев, \& Нестик, 2012).

Для оцінки вираженості та спрямованості рефлексії до і після впровадження програми було застосовано опитувальник М. Гранта, який складається із двох шкал - ауторефлексії і соціорефлексії (Grant, 2001; Карпов, \& Скитяева, 2005). Високий рівень соціальної рефлексії забезпечує виражені соціальні потреби в повазі, визнанні, теплих стосунках з іншими і в цілому орієнтацію на групу. Рівень саморефлексії пов'язаний з аналізом почуттів та переживань щодо самого себе, внутрішнього діалогу iз самим собою. За результатами дослідження рефлексії на початку корекційних занять, $60 \%$ досліджуваних виявили високий рівень ауторефлексії та середній рівень соціорефлексії; 15\% низький рівень ауторефлексії і дещо нижчий від середнього рівень соціорефлексії; у решти ауторефлексія і соціорефлексія мали середній рівень прояву. Після корекційно-розвивального впливу, 3 огляду на результати аналізу співвідношення цих двох форм рефлексій, зафіксовано підвищення показників за шкалою соціорефлексії $(\mathrm{p} \leq 0,05)$ та зміщення показників ауторефлексії від високих до дещо вище середніх, від низьких до середніх $(\mathrm{p} \leq 0,05)$. Відповідно до інтерпретації результатів за опитувальником співвідношення середнього рівня ауторефлексії та вище середнього й високого рівня соціорефлексії визнається найбільш адаптивним.

Аналіз результатів дослідження самоефективності та відчуття зв'язаності до і після проведених занять засвідчив наявність змін за цими показниками. Так, статистично значущі відмінності виявлено за показниками загальної самоефективності $(\mathrm{p} \leq 0,01)$ та інтегрального показника відчуття зв'язності $(\mathrm{p} \leq 0,05)$, рівень яких значно підвищився.

Результати ефективності проведеної корекційно-розвивальної роботи також було проаналізовано за суб'єктивно-оцінним критерієм шляхом залучення механізмів рефлексї щодо задоволення від роботи, оцінки інформативної насиченості програми та можливостей і бажання застосовувати набуті навички та вміння. Такий аналіз було зроблено завдяки рефлексії наприкінці кожного заняття, а також під час підбиття загальних підсумків роботи і за результатами опитування учасників щодо ефективності програми. Учасникам було запропоновано обрати один із трьох варіантів відповідей (так, ні, важко сказати) для кожного пункту із запропонованих тверджень.

У результаті проведеної роботи відбулося усвідомлення:

- своїх якостей, сильних та слабких сторін; 
- своїх негативних переживань та здатності з ними впоратися;

- своїх типових реакцій на складні життєві обставини;

- різних ресурсів подолання наслідків кризових подій;

- значення соціальної підтримки в процесі подолання наслідків складних життєвих ситуацій;

- важливості активної участі в діяльності, спрямованій на зміцнення здоров'я.

Активізувалися процеси:

- здатності бачити одне й те саме явище під різними кутами зору;

- оптимізації наявних психологічних стратегій адаптації та вироблення нових;

- самовизначення у сфері здоров'я;

- пошуку нових можливостей та прихованих ресурсів.

Відбулося посилення:

- упевненості в собі, віри у свої сили та можливості;

- відповідальності за свої рішення та вибори;

- відповідальності у ставленні до здоров'я;

- довіри до інших та відчуття підтримки з боку інших;

- готовності змінюватися;

- віри у здатність підвищувати якість життя та благополуччя як на індивідуальному, так

і на колективному рівнях.

У цілому частка учасників, які дали ствердну відповідь щодо ефективності програми, становила 92\%, решті осіб було важко визначитися з відповіддю на ті чи інші запитання.

Як показали результати апробації засобів підвищення адаптивності та зміцнення громадського здоров'я, в основу яких покладено означену модель, активізація цих ресурсів, врахування та нарощування адаптаційного потенціалу спільноти сприяють посиленню самоефективності та відчуття зв'язності як здатності протистояти негативним зовнішнім впливам, підтримувати та підвищувати рівень благополуччя як базової ознаки індивідуального та громадського здоров’я.

Корекційний вплив може бути суттєво посилений за рахунок більшої тривалості корекційної програми та включення в неї терапевтичного складника, зокрема для опрацювання негативних станів і травматичного самоусвідомлення.

Практична/соціальна значущість дослідження. Упровадження запропонованих засобів сприятиме активізації індивідуальних і колективних ресурсів підвищення адаптивності та зміцнення здоров'я, спонукатиме представників спільноти до вироблення проактивно-трансформаційних психологічних стратегій як найбільш ефективного варіанта індивідуальної i колективної зараджувальної поведінки в різних сферах життєдіяльності, зокрема в процесі зміцнення громадського здоров'я.

Висновки. Розроблені та апробовані соціально-психологічні засоби засвідчили ефективність щодо підвищення адаптивності спільноти до наслідків воєнного конфлікту завдяки активізації готовності змінюватися, зростати, брати відповідальність на себе; орієнтації на розвиток індивідуальних і колективних ресурсів адаптації; набуттю знань та навичок, які сприяють підвищенню благополуччя; актуалізації та активізації рефлексивних процесів; оптимізації наявних та виробленню більш ефективних стратегій адаптації.

Вироблення стратегій, які мають внутрішню зумовленість, проявляються в здатності протистояти зовнішнім впливам та активно протидіяти їм, орієнтуватися на майбутнє і які реалізуються, зокрема, у процесі зміцнення як індивідуального, так і громадського здоров'я (як досягнення благополуччя), можливе завдяки змінам у свідомості громадян щодо самовизначення у сфері здоров'я, підвищення їхньої відповідальності у ставленні до нього; розширенню мережі зв'язків між членами спільноти; активізації процесів самоорганізації та самоефективності, рефлексивних процесів, консолідації колективних зусиль на подолання наслідків воєнного конфлікту та досягнення благополуччя.

Перспективу дальших досліджень убачаємо в посиленні громадської уваги до проблем адаптації спільнот в умовах воєнного конфлікту, усвідомлення членами спільнот можливостей підвищення їхньої індивідуальної та колективної адаптації; у формуванні готовності лідерів та активістів використовувати психологічні засоби корекції поведінки спільнот в умовах соціальних викликів. 


\section{Список використаних джерел}

Бандура, А. (2000). Теория соииального научения. Санкт-Петербург: Евразия.

Журавлев, А. Л. (2009). Коллективный субъект: основные признаки, уровни и психологические типы. Психологический журнал, 5 (30), 72-80.

Журавлев, А. Л., \& Нестик, Т. А. (2012). Групповая рефлексивность: основные подходы и перспективы исследований. Психологический журнал, 4 (33), $27-37$.

Карпов, А. В., \& Скитяева, И. М. (2005). Психология метакогнитивных прочессов личности. Москва: Институт психологии РАН.

Климчук, В. О. (2016). Посттравматичне зростання та як можна йому сприяти у психотерапії. Наука $i$ освіта, 5 (16), 46-52.

Коробка, Л. М. (2018). Психологічні стратегії як засоби реалізації індивідуальної та колективної адаптації до наслідків воєнного конфлікту. Наукові студії із соціальної та політичної психології НАПН України, 41 (44), 46-56.

Кривоконь, Н. I. (2015). Соціально-психологічна підтримка як чинник подолання скрутних життєвих ситуацій. Проблеми сучасної психології: збірник наукових пращь К-ПНУ імені Івана Огієнка, Інституту психології імені Г. С. Костюка НАПН Украӥни, (29), 319-328.

Найдьонова, Л.А. (2015). Інтеграція вітчизняної психологічної науки і практики психологічної реабілітації військових: про розвиток рефлексивних властивостей психологічної спільноти. Актуальні проблеми соиіології, психології, педагогіки, 4 (29), 106-111.

Antonovsky, A. (1984). The Sense of Coherence as a Determinant of Health. Advances, Institute for Advancement of Health, 1 (3), 37-50.

Antonovsky, A. (1996). The salutogenic model as a theory to guide health promotion. Health Promotion International, 11 (1), 11-18.

Bonanno, G. A. (2004). Loss, Trauma, and Human Resilience: Have We Underestimated the Human Capacity to Thrive After Aversive Events? American Psychologist, 59 (1), 20-28.

Grant, A. M. (2001). Rethinking psychological mindedness: metacognition, self-reflection, and insight. Behaviour Change, 18, 8-17.

Joseph, S., \& Linley, P. A. (2006). Positive psychology versus the medical model? American Psychologist, 61 (4), 332-333.

Norris, F. H., Stevens, S. P., \& Pfefferbaum, B. (2008). Community Resilience as a Metaphor, Theory, Set of Capacities, and Strategy for Disaster Readiness. American Journal of Community Psychology, 41 (1-2), 131-134.

Tedeschi, R. G., \& Calhoun, L. G. (2004). Posttraumatic growth: conceptual foundations and empirical evidence. Psychological Inquiry, 15 (1), 1-18.

\section{References}

Antonovsky, A. (1996). The salutogenic model as a theory to guide health promotion. Health Promotion International, 11 (1), 11-18. (in English)

Antonovsky, A. (1984). The Sense of Coherence as a Determinant of Health. Advances, Institute for Advancement of Health, 1 (3), 37-50. (in English) (in Russian)

Bandura, A. (2000). Teoriya sotsialnogo naucheniya [Theory of social study]. St. Petersburg: Evraziya Publ.

Bonanno, G. A. (2004). Loss, Trauma, and Human Resilience: Have We Underestimated the Human Capacity to Thrive After Aversive Events? American Psychologist, 59 (1), 20-28. (in English)

Grant, A. M. (2001). Rethinking psychological mindedness: metacognition, self-reflection, and insight. Behaviour Change, 18, 8-17. (in English)

Joseph, S., \& Linley, P. A. (2006). Positive psychology versus the medical model? American Psychologist. 61 (4), 332-333. (in English)

Karpov, A. V., \& Skityayeva, I. M. (2005). Psikhologiya metakognitivnykh protsessov lichnosti [Psychology of metacognitive processes of personality]. Moscow: Institut psikhologii RAN. (in Russian)

Klymchuk, V. O. (2016). Posttravmatychne zrostannia ta yak mozhna yomu spryiaty u psykhoterapii [Posttraumatic growth and ways of facilitating it in psychotherapy]. Nauka i osvita [Science and education], 5 (16), 4652. (in Ukrainian)

Korobka, L. M. (2018). Psykholohichni stratehii yak zasoby realizatsii indyvidualnoi ta kolektyvnoi adaptatsii do naslidkiv voiennoho konfliktu [Psychological strategies as means of implementation of individual and collective 
adaptation to the consequences of armed conflict]. Naukovi studii iz sotsialnoi ta politychnoi psykholohii NAPN Ukrainy, 41 (44), 46-56. (in Ukrainian)

Kryvokon, N. I. (2015). Sotsialno-psykholohichna pidtrymka yak chynnyk podolannia skrutnykh zhyttievykh sytuatsii [Social and psychological support as a factor in overcoming difficult life situations]. Problemy suchasnoi psykholohii: zbirnyk naukovykh prats K-PNU imeni Ivana Ohiienka, Instytutu psykholohii imeni H. S. Kostiuka NAPN Ukrainy, (29), 319-328. (in Ukrainian)

Naydonova, L. A. (2015). Intehratsiia vitchyznianoi psykholohichnoi nauky i praktyky psykholohichnoi reabilitatsii viiskovykh: pro rozvytok refleksyvnykh vlastyvostei psykholohichnoi spilnoty [Integration of the domestic psychological science and the practice of psychological rehabilitation of the military: the development of reflexive properties of the psychological community] Aktualni problemy sotsiolohii, psykholohii, pedahohiky, 4 (29), 106-111. (in Ukrainian)

Norris, F. H., Stevens, S. P., \& Pfefferbaum, B. (2008). Community Resilience as a Metaphor, Theory, Set of Capacities, and Strategy for Disaster Readiness. American Journal of Community Psychology, 41 (1-2), 131-134. (in English)

Tedeschi, R. G., \& Calhoun, L. G. (2004). Posttraumatic growth: conceptual foundations and empirical evidence. Psychological Inquiry, 15 (1), 1-18. (in English)

Zhuravlev, A. L. (2009). Kollektivnyy subyekt: osnovnyye priznaki, urovni i psikhologicheskiye tipy [Collective subject: main features, levels and psychological types]. Psikhologicheskiy zhurnal, 5 (30), 72-80. (in Russian)

Zhuravlev, A. L., \& Nestik, T. A. (2012). Hruppovaya refleksivnost: osnovnyye podkhody i perspektivy issledovaniy [Group reflexivity: the main approaches and perspectives of research]. Psikhologicheskiy zhurnal, 4 (33), 27-37. (in Russian) 